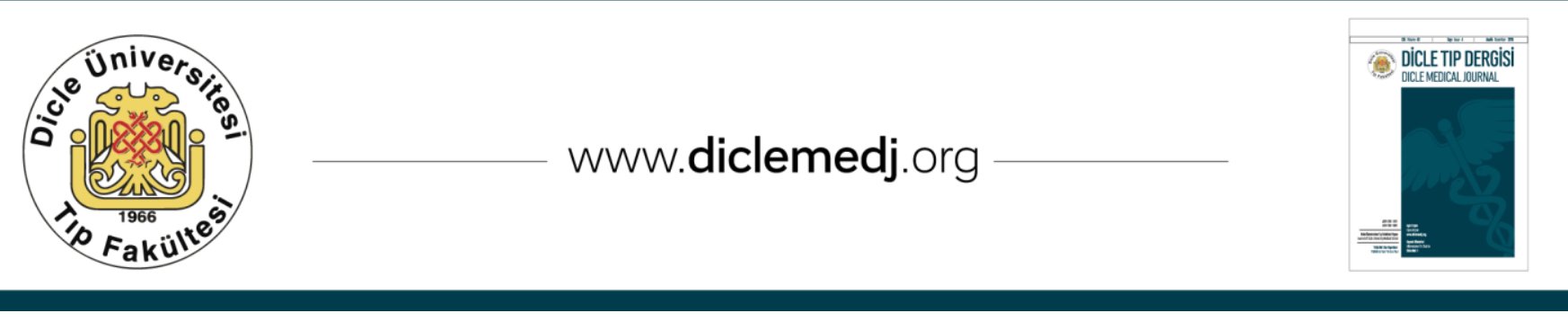

Original Article / Özgün Araştırma

\title{
Unusual Histopathological Findings of Intradermal Nevus: Retrospective Analysis of 2640 Cases
}

\section{Nilgun Sogutcu 1}

1 Dept of Pathology, Univ. of Health Sciences Gazi Yasargil Education and Research Hospital, 21400, Diyarbakir, Turkey ORCID: 0000000224552964

Received: 24.05.2019; Revised: 09.08.2019; Accepted: 19.08.2019

\begin{abstract}
Objective: Intradermal nevi are benign tumors of the skin and may be accompanied by different histopathological findings. The aim of this study was to assess co-existing unusual histopathological findings in specimens resected with a preliminary diagnosis of an intradermal nevus.

Method: We retrospectively examined demographic and histopathological data of 2640 cases resected with a preliminary diagnosis of an intradermal nevus between January 2010 and April 2018.

Results: A total of 1973 women and 667 men with an age range of 2.8 to 94 years were enrolled. Among cases having a histopathological diagnosis of intradermal nevus, 46 cases had unusual histopathological findings, which included 21 osseous metaplasia, 8 epidermal cysts, 4 folliculitis, 1 seborrheic keratosis, 1 verruca vulgaris, 1 cavernous hemangioma-intravascular papillary endothelial hyperplasia, 1 trichofollicoma, 1 sebaceous hyperplasia, 1 pilonidal sinus, 1 granulomatous inflammation, 1 basal cell carcinoma, 4 foreign body reactions, and 1 Demodex spp.

Conclusion: Although unusual histopathological findings were observed in a minority of cases with intradermal nevi, it was noted that problems with differential diagnosis may arise in some cases. Intradermal nevi need to be carefully examined for potential co-existing neoplastic lesions.
\end{abstract}

Keywords: Intradermal nevus; Osteonevus of Nanta; Unusual histopathological findings

DOI: $10.5798 /$ dicletip.569680

Yazışma Adresi / Correspondence: Nilgun Sogutcu, Department of Pathology University of Health Sciences Gazi Yasargil Education and Research Hospital, 21400, Diyarbakir, Turkey, e-mail: nilgunsogutcu@gmail.com 


\section{İntradermal Nevuse Eşlik Eden Olağan Dışı Histopatolojik Bulgular: 2640 Vakanın Retrospektif Analizi}

\section{Öz}

Amaç: İntradermal nevüsler cildin iyi huylu tümörleridir ve bu tümörlere farklı histopatolojik bulgular eşlik edebilir. $\mathrm{Bu}$ çalışmanın amacı, intradermal nevüs ön tanısı ile rezeke edilen örneklere eşlik eden olağandışı histopatolojik bulguları değerlendirmektir.

Yöntemler: Ocak 2010-Nisan 2018 tarihleri arasında intradermalnevüs ön tanısı alan 2640 olgunun demografik ve histopatolojik verileri retrospektif olarak incelendi.

Bulgular: İntradermal nevüs tanılı, yaşları 2.8 ile 94 arasında değişen toplam 1973 kadın ve 667 erkek çalışmaya dahil edildi. Histopatolojik olarak intradermal nevüs tanısı alan olguların 46'sına farklı histopatolojik bulgular eşlik ediyordu. 21 vakada osseous metaplazi, 8 vakada epidermal kist, 4 vakada follikülit, 1 vakada seboreik keratoz, 1 vakada verruka vulgaris, 1 vakada kavernöz hemanjiyom-intravasküler papiller endotelyal hiperplazi, 1 vakada trikofoliküloma, 1 vakada sebaseöz hiperplazi, 1 vakada pilonidal sinus, 1 vakada granulomatöz inflamasyon, 1 vakada bazal hücreli karsinom, 4 vakada yabancı cisim reaksiyonu ve 1 vakada Demodexspp. saptandı.

Sonuç: İntradermalnevüs tanılı hastaların küçük bir kısmına olağandışı histopatolojik bulgular eşlik etmesine rağmen, bazı olgularda ayırıcı tanı ile ilgili sorunların ortaya çıkabileceği kaydedilmiştir. İntradermal nevüslerin eşlik eden potansiyel neoplastik lezyonlar açısından dikkatle incelenmesi gerekir.

Anahtar kelimeler; İntradermal nevüs; Nanta osteonevusu; Olağandışı histopatolojik bulgular.

\section{INTRODUCTION}

Many interesting lesions infrequently co-exist with an intradermal nevus ${ }^{1}$. Some of these lesions are osseous metaplasia, cysts, foreign body reaction, and tumors of epidermal and adnexial origin ${ }^{2,3}$. Incidental bone formation in intradermal nevus is known as osteonevus of Nanta. Seen as a rare phenomenon, bone formation in the skin may be primary or secondary.

Historically, primary cases have comprised entities as progressive osseous heteroplasia, Albright hereditary osteodystrophy, myositis ossificansprogressiva, diaphysealaclasis, and osteoma cutis. Secondary bone formation has been pronounced in a variety of lesions as pilomatricoma, basal cell carcinoma, acnea, melanocytic nevus, cellular nevus, cylindroma, and dermatofibroma ${ }^{3}$. The aim of the present study was to draw attention to unusual histopathological findings in specimens that were resected with a preliminary diagnosis of intradermal nevus, and to increase the awareness of dermatopathologists of this subject.

\section{METHOD}

This study was approved by Hospital Clinical Research Ethics Committee (Approval No: 2018/136). Demographic and histopathological data of 2640 patients that presented to University of .............. Hospital with a preliminary diagnosis of an intradermal nevus between January 2010 and April 2018 were retrospectively analyzed. The patients with an unusual histopathology were determined from medical records. All patients' slides were examined and confirmed by an expert pathologist. New sections were prepared from paraffin-embedded blocks when needed.

The sections were stained with Hematoxylin \& Eosin, but no other special staining was performed. All patients' macroscopic and microscopic features and theco-existing unusual histopathological findings were recorded. All clinical information pertaining to 
the patients including age, sex, and lesion location were obtained from the hospital automation system.

\section{RESULTS}

Total of 1973 women and 667 men with an age range of 2.8 to 94 years were enrolled. Fortysix $(1.7 \%)$ patients found to have unusual histopathological findings. They had an age range of 17 to 74 years [mean age (SD): 34.3 (11.8) years]; thirteen (28.2\%) were male and $33(71.7 \%)$ were female. The male patients had an age range of 17 to 49 years [mean age: 29.6 (10.7) years] and the females 17 to 74 years [mean age 35.7 (11.9) years]. Forty-four lesions were located in the head-neck region; one in the back; and one in the left arm. The general characteristics of the patients were presented on Table 1.

Table 1: General characteristics of the patients with unusual histopathological findings

\begin{tabular}{|l|c|c|c|c|}
\hline $\begin{array}{l}\text { Histopathological } \\
\text { Findings }\end{array}$ & $\mathbf{n}$ & $\mathbf{\%}$ & Male & Female \\
\hline Osseous metaplasia & 21 & 45.6 & $18(85.7 \%)$ & $3(14.2 \%)$ \\
\hline Epidermal cyst & 8 & 17.3 & $3(37.5 \%)$ & $5(62.5 \%)$ \\
\hline Trichofolliculoma & 1 & 2.1 & 1 & \\
\hline IPEH & 1 & 2.1 & 1 & \\
\hline Demodeks spp. & 1 & 2.1 & & 1 \\
\hline Folliculitis & 4 & 8.6 & & 4 \\
\hline FBR & 4 & 8.6 & 2 & 2 \\
\hline GIP & 1 & 2.1 & & 1 \\
\hline Verruca vulgaris & 1 & 2.1 & 1 & \\
\hline BCC & 1 & 2.1 & & 1 \\
\hline Seborrheickeratosis & 1 & 2.1 & & 1 \\
\hline $\begin{array}{l}\text { Sebaseous } \\
\text { hyperplasia }\end{array}$ & 1 & 2.1 & & 1 \\
\hline Pilonidal sinus & 1 & 2.1 & & 1 \\
\hline
\end{tabular}

IPEH: Intravascular Papillary Endothelial Hyperplasia, FBR: Foreign Body Reaction, GIP: Granulomatous Inflammatory Process, BCC: Basal Cell Carcinoma
The most common unusual histopathological finding co-existing within intradermal nevus was osseous metaplasia (osteonevus of Nanta) $(n=21)$. The age range of those patients having osseous metaplasia was 17 to 74 years [mean age: 33.19 (10.2) years]. Among them, 18 $(85.7 \%)$ were female and $3(14.2 \%)$ were male. The lesions were located in the head-neck region in 20 patients, and in the left arm in one patient. Among those located in the head-neck region, 15 lesions were located in the cheek, 2 in the forehead, 1 in the nose, 1 in the chin, and 2 in the neck region. The nevi are usually accompanied by a single focus of ossification. However, four patients had more than one focus of ossification. Bone formation was outside the nevoid clusters in most cases (Fig.1A) and was intermingled with nevoid cells in only 2 cases (Fig. 1B). In all cases bone formation outside nevoid clusters was located basally to the nevoid cells. Chronic inflammation encircling the lesion was present in 6 patients. One patient a hadgranulamatous inflammatory reaction around the bone formation.

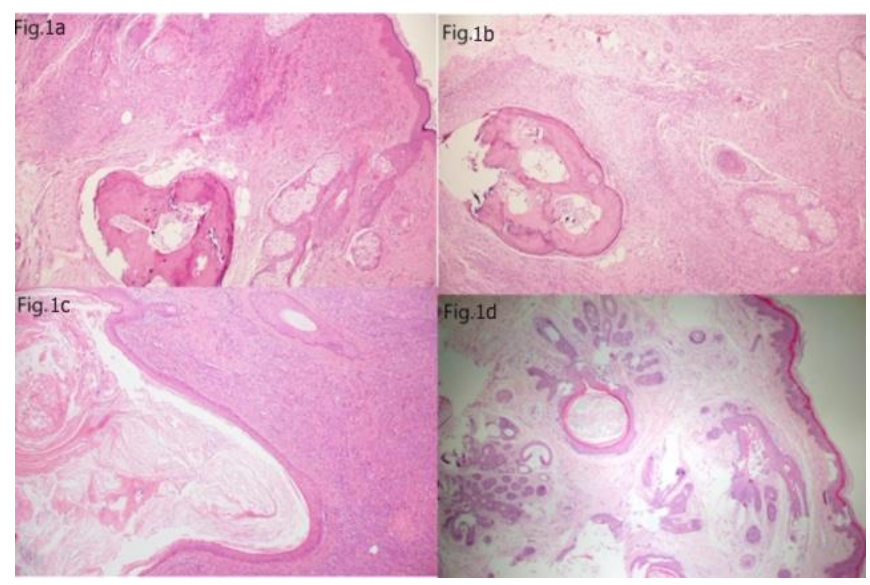

Fig.1: (A): Compact bone tissue with bone marrow at the base of nevoid cells (HE x100), (B): Compact bone tissue that is nested with nevoid cells (HE x100), (C): Cystic lesion with squamous epithelium containing keratinous material and adjacent nevoid cell (HE x40), (D): Have central dilated follicle surronded by proliferating epithelium with various phases of follicle formation (HE $\mathrm{x} 400)$. 
Another unusual histopathological finding accompanying intradermal nevus was an epidermal cyst, which was seen in 8 patients. The patient age range was 17 to 45 years [mean age: 31.7 (11.0) years], and $3(37.5 \%)$ patients were male and $5(62.5 \%)$ were female. All lesions were located in the head-neck region, with six lesions being located in the face and 2 in the cheek. No lesion was located in the neck. Epidermal cyst dimensions were variable, with the largest being of $7 \mathrm{~mm}$ in size (Fig.1C).One of the cases had a trichofolliculoma adjacent to an intradermal nevus. That patient was a 25 -yearold man with a lesion located in the face (Figure 1D).The histopathological examination of the skin biopsy revealed a hemangioma with an adjacent intravascular papillary endothelial hyperplasia and intradermal nevus in a 49year-old man with a lesion located in the neck (Fig. 2A,B).

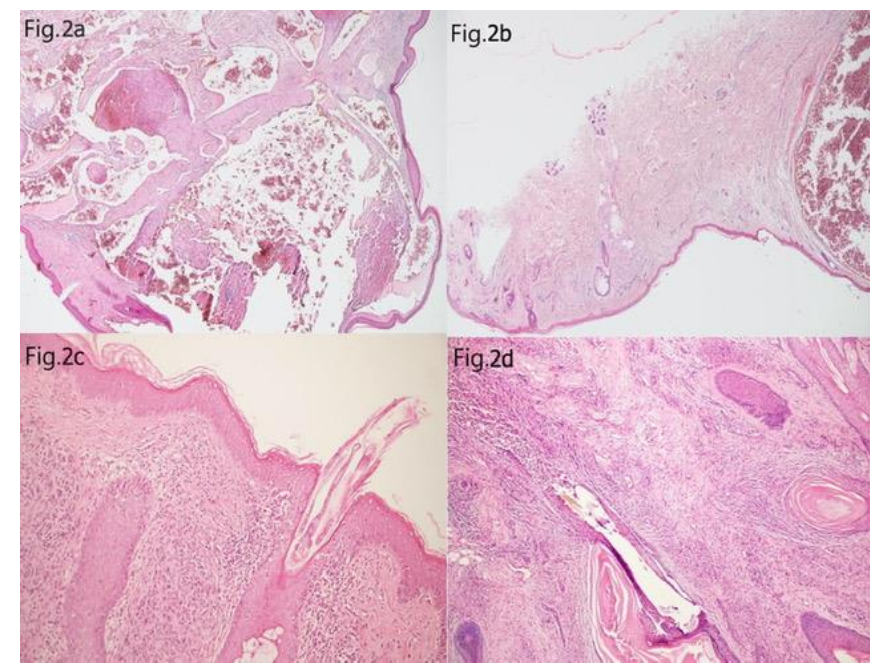

Fig.2: (A): Intravascular papillary endothelial hyperplasia stratified squamous epithelium (HE x40), (B): The focus of the hemangioma on the right side of the image, intradermal nevus on the left side (HE x40), (C):Demodex at the hair follicle with nevus cells belonging to the intradermal nevus under a stratified squamous epithelium (HE x20), (D): Nevus cells with ruptured hair follicle and chronic inflammatory process involving foreign body tissue reaction (HE x100).

The microscopic examination of a biopsy material showed Demodexspp accompanying an intradermal nevus in a 48-year-old female. That lesion was located in the face and had a size of $0.4 \mathrm{~cm}$ (Fig.2C). Four cases of foreign body reactions and 4 cases of folliculitis were identified. All patients with folliculitis were women with lesions being located in the face region. The intradermal nevi accompanied by a foreign body reaction were seen in 2 males and 2 female patients, with the lesions being located in the face region (Fig.2D).

The case series involved a 32-year-old woman who had an intradermal nevus located in the face region, which was accompanied by a granulomatous inflammatory reaction containing giant cells around the pilosebaceous unit (Fig.3A).

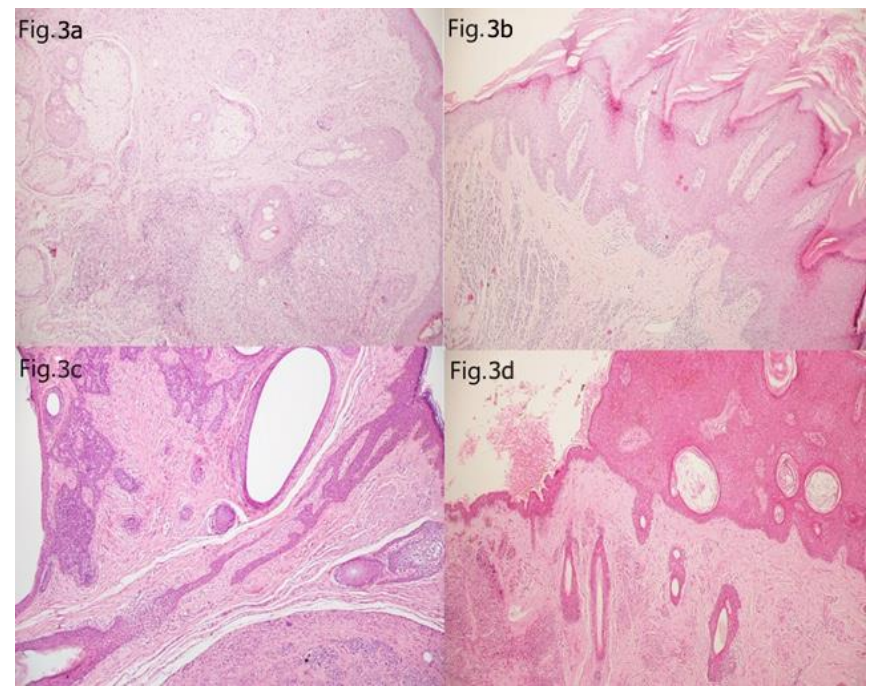

Fig.3: (A): Granuloma consisting of multinuclear giant cells, epitheloidhistiocytes and lymphocytes in the lower half of the picture with nevus cells (HE x100), (B): Intradermal localized nevus cells with stratified squamous epithelium showing papillomatosis with prominent areas of hyperkeratosis and parakeratosis (HE x100), (C): Basal cell carcinoma in the upper half of the image and intradermal nevus cells in the lower half (HE x100), (D): Intradermal nevus cells in squamous epithelium with papillomatosis, appearance cutaneous horn (HE x100).

The histopathological examination of the biopsy material revealed an intradermal nevus accompanied by a verruca vulgaris in a 32year-old man referred to our clinic with the 
preliminary diagnosis of a papilliform lesion in the scalp (Fig.3B).The histopathological examination of the skin biopsy material of a patient referred for a preliminary diagnosis of a benign skin neoplasm showed the co-existence of a basal cell carcinoma and an intradermal nevus. That patient was a 74-year-old woman with a lesion located on the nose (Fig.3C).One patient in our case series had co-existing seborrheic keratosis and an intradermal nevus. That patient was a 52-year-old woman with a lesion located in the face region (Fig.3D). The histopathological examination of the cheek skin biopsy material of a 22-year-old woman showed both an intradermal nevus and sebaceous hyperplasia

\section{DISCUSSION}

Many unusual changes may infrequently coexist with intradermal melanocytic nevi ${ }^{1}$. Cutaneous bone formation is a rare phenomenon, which develops in the skin either primarily (except for other already existing lesions, such as osteoma cutis) or secondarily (usually occurring in relation to inflammatory or neoplastic processes such as basal cell carcinoma and acnea) ${ }^{2,3}$.Bone formation is usually present at the base of melanocytic lesions, which are located in the upper body parts, as is the case in our study. The origin of ossification inside a melanocytic nevus is not entirely clear. Many different theories have been put forward to explain such unusual findings.

Burgdorf and Nasemann asserted two mechanisms as to the cause of cutaneous ossification: 1) transformation of primitive mesenchymal cells into bone-forming osteoblasts. 2) metaplasic transformation of other unidentified dermal cells, induced by a suitable cellular medium ${ }^{2}$.Keida et all. ${ }^{4}$ suggested that transforming growth factor- $\beta$ and connective tissue growth factor play a role for development of ossification in intradermal nevi. Conlinet al3 advocated that an increase in alkaline phosphatase and osteonectin activities play a role in the formation of cutaneous ossification. In addition to the presence of fibroblasts, osteoblasts cause osteonectin and type 1 collagen accumulation around the bone formation. Fibroblasts, one of the probable agents responsible for bone formation, may transform to bone forming units independently of the presence of a stimulus ${ }^{3}$. Despite many hypotheses, the search for the cause of osteoid tissue formation is still incomplete. Moreover, this phenomenon has a higher incidence in women.

This interesting observation remains largely unexplained. It is a well-known fact that osteoblasts possess surface receptors for estrogens. This interaction causes the release cytokines, which in turn results in downregulation of bone resorbtion as in osteoporosis. Hence, while one considers that the effects of estrogens on osteoblasts, coupled with a deficient osteoclastic activity, may explain the increased incidence of these lesions are more common in women, this attractive hypothesis needs to be confirmed by additional studies $^{5}$. In the present study there were 21 patients with osteoid metaplasia. In agreement with the literature, 18 of these cases were female and 3 were male.

Some intradermal nevi show signs of hyperkeratosis and papillomatosis; these may be related to a downward growth of epidermal structures and horn cysts. Such nevi show similarity with seborrheic keratosis with their own epidermal structures 5 . In this case series there were one case appearing as such.

In some cases, large hair follicles may accompany intradermal nevi. The rupture of a large hair follicle may become evident with increasing nevus size associated with an inflammatory reaction, which clinically raise the suspicion of a melanoma. In these instances, a histological examination shows an epidermal follicular structure partially destroyed by a 
marked inflammatory infiltrate containing foreign body giant cells, which appears as a reaction to keratin found in the dermis ${ }^{6}$. In this case series a total of 8 cases were described, of which 4 showed signs of folliculitis and 4 foreign body reactions.

Some researchers have suggested that nevus cells exerting pressure upon hair follicles may result in obstruction and cyst development. Alternatively, cysts may occur as a result of a pilosebaceous follicle being strangulated by a fibrotic process associated with nevus maturation ${ }^{7}$.This study identified 8 cases with epidermal cyst formation.

Trichofolliculoma is a rare type of hamartoma that mostly occurs in adults as a small, solitary papule or nodule ${ }^{8}$.Although its exact etiology is unclear, it is believed to develop from an abortive differentiation of pluripotent derm cells toward hair stems ${ }^{9}$.Trichofolliculoma is a benign tumor, although perineural invasion and malignant transformation has been reported in a single case ${ }^{10}$. The co-existence of a trichofolliculoma and a melanocytic nevus reported here is the second case after theone reported by Bolteet all. ${ }^{11}$, who demonstrated that melanocytic clusters encircled hair follicle in a 47-year-old male with a lesion in his left cheek. Herein, it has been identified that a 25year-old man with a lesion localization in the cheek region.

Although the co-existence of congenital melanocytic nevi and hemangiomas has been already described, it has been reported in only a few adult cases. Tognettiet all. ${ }^{12}$ reported a combination of a melanocytic nevus and a hemangioma in 5 cases. Although melanocytic tumors and hemangiomas were well defined lesions in that study, specific studies about the combination of the two lesions are reportedly insufficient. Our literature review did not reveal any report of the co-existence of an intradermal nevus and a cavernous hemagioma-intravascular papillary endothelial hyperplasia. In the present study, one patient had a hemangioma focus and an adjacent intravascular papillary endothelial hyperplasia and intradermal nevus, all identified in the same biopsy material. That patient was 49 years old and his lesion was located in the neck region.

Seneret all. ${ }^{13}$ reported a relationship between Demodex spp. and melanocytic nevi, and a greater rate of parasite in patients with intradermal nevus compared to the normal population. In that study, 110 patients with nevi were examined, $39.1 \%$ of which were found positive for Demodexspp. The present study revealed only one case with the parasite, and this result is inconsistent with the report of Seneret all. This inconsistency may have resulted from both a small sample size and the geographical-socioeconomic status of the study region.

Verruca vulgaris is a benign proliferative lesion caused by HPV. As far as is known, it has no pathophysiological relationship with melanocytic nevi. Apart from a case reported by Y.W. Park et all, such a co-existence has not been reported. The authors have attributed the co-existence of the two lesions to HPV infection that developed secondary to repeated irritation and minor trauma in nevoid lesions ${ }^{14}$. Their study also described the co-existence of an intradermal nevus and a verruca vulgaris lesion.

Collosion tumors, which are characterized by co-existence of two tumors in the same anatomic region, have an unclear pathogenesis. Albeit rare, the co-existence of a basal cell carcinoma and a melanocytic nevus is the most common one skin tumor combination ${ }^{15}$.In the present study one case of an intradermal nevus co-existing with a basal cell carcinoma was observed among 2640 cases.

The co-existence of a melanocytic tumor and seborrheic keratosis has been reported in a limited number of cases. Chong et all. ${ }^{16}$ 
reviewed their own case and a total of 25 cases reported in various studies.That study also described a case having co-existing benign intradermal melanocytic tumor and seborrheic keratosis.

This study assessed unusual histopathological findings accompanying melanocytic nevi. Although unusual histopathological findings were observed in a minority of cases with intradermal nevi, it was noted that problems with differential diagnosis may arise in some cases. Intradermal nevi need to be carefully examined for potential co-existing neoplastic lesions.

Conflicts of interest: The authors have no conflict of interests to declare.

Financial Disclosure: The authors declared that this study has received no financial support.

\section{REFERENCES}

1. Sasaki S, Mitsuhashi Y, Ito Y. Osteo-nevus of Nanta: a case report and review of the Japanese literature. J Dermatol. 1999; 26: 183-8.

2. Burgdorf W, Nasemann T. Cutaneous osteomas: a clinical and histopathologic review. Arch Dermatol Res. 1977; 260: 121-35.

3. Conlin PA, Jimenez-Quintero LP, Rapini RP. Osteomas of the skin revisited: a clinicopathologic review of 74 cases. Am J Dermatopathol. 2002; 24: 479-83.

4. Keida T, Hayashi N, Kawakami M, Kawashima M. Transforming growth factor beta and connective tissue growth factor are involved in the evolution of nevus of Nanta. J Dermatol. 2005; 32:442-5.

5. Al-Daraji W. Osteo-nevus of Nanta (osseous metaplasia in a benign intradermal melanocytic nevus): an uncommon phenomenon.Dermatol Online J. 2007; 13:16.
6. Elders DE, Elenitsas R, Murphy GF, Xu X.Benign Pigmented Lesions and Malignant Melanoma.In: Elders DE, ElenitsasR,editors.Lever's Histopathology of Skin. Philadelphia: Lippincott Williams and Wilkins; 2009.p.699-791.

7. Freeman RG, Knox JM. Epidermal cysts associated with pigmented naevi. Arch Dermatol. 1962; 85:726.

8. Kurokawa I, Kusumoto K, SensakiH,et all. Trichofolliculoma: Case report with immunohistochemical study of cytokeratins. Br J Dermatol. 2003; 148:597-8.

9. Schulz T, Hartschuh W. The trichofolliculoma undergoes changes corresponding to the regressing normal hair follicle in its cycle. J CutanPathol. 1998; 25:341-53.

10. Stern JB, Stout DA. Trichofolliculoma showing perineural invasion. Trichofolliculocarcinoma? Arch Dermatol. 1979; 115:1003-4.

11. Bolte C, Cullen R, Sazunic I. Collision Tumor between Trichofolliculoma and Melanocytic Nevus.2017; 9:181-3.

12. Tognetti L, Cinotti E, Perrot JL, etall.Benign and malignant collision tumors of melanocytic skin lesions with hemangioma: Dermoscopic and reflectance confocal microscopy features. Skin Res Technol. 2018;24:313-7.

13. Sener S, Karaman U, Colak C, et all.Positivity of Demodex spp. in biopsy specimens of nevi. Tropical Biomedicine.2009; 26: 51-6.

14. Park YW, Yoon SY, Paik SH, et all. Verruca vulgaris on top of a melanocyte nevus simulating melanoma. Korean J Dermatol 2012; 50: 923-4.

15. Boyd AS, Rapini RP. Cutaneous collision tumors. An analysis of 69 cases and review of the literature. Am J Dermatopathol. 1994; 16: 253-7.

16. Chong $\mathrm{Y}$, Song DH, Jang KT, Park KH, Lee EJ. Concurrent Occurrence of Seborrheic Keratosis and Melanocytic Nevus in the Same Lesion. NaszaDermatologiaOnline. 2014; 5: 179-82. 